\title{
PENERAPAN MODEL PEMBELAJARAN KOOPERATIF TIPE TGT (TEAM GAMES TOURNAMENT) DALAM MENINGKATKAN MOTIVASI BELAJAR IPS DI KELAS VII-5 SMP NEGERI 3 PERCUT SEI TUAN
}

\author{
Idawati Br. Ginting \\ Guru SMP Negeri 3 percut Sei Tuan, Kabupaten Deli Serdang \\ Surel: indrawanabdullah@gmail.com
}

\begin{abstract}
Abstrak
Penelitian ini bertujuan untuk meningkatkan motivasi belajar siswa pada Mata Pelajaran IPS setelah penerapan model Kooperatif Tipe TGT (Team Games Tournament). Hasil penelitian menunjukkan peningkatan motivasi belajar siswa yang bermotivasi tinggi dari $16.67 \%$ dengan rerata capaian $43.99 \%$ dari indikator motivasi belajar pada observasi awal, meningkatan menjadi $33.33 \%$ dengan rerata capaian $46.40 \%$ pada pertengahan siklus I dan menjadi $61.11 \%$ dengan rerata capaian $69.62 \%$ pada akhir siklus I. Pada pertengahan siklus II siswa yang bermotivasi tinggi naik mencapai $80.56 \%$ dengan rerata capaian $75.09 \%$, dan di akhir siklus II mencapai $91,67 \%$ dengan rerata capaian $80.99 \%$ dari indikator motivasi belajar siswa.
\end{abstract}

Kata Kunci : Team Games Tournament, Metode Pembelajaran

\section{PENDAHULUAN}

Materi pembelajaran Ilmu Pengetahuan Sosial (IPS) merupakan pembelajaran yang berorientasi kepada lingkungan sosialn, melalui mata pelajaran ini peserta didik dikenalkan kepada lingkungan di sekitarnya, kemampuan bersikap dan memiliki berkarakter kebangsaan. Menurut Muhammad Nuh (2014), pembelajaran IPS ditujukan untuk memberikan wawasan yang utuh bagi siswa tentang konsep konektivitas ruang dan waktu beserta aktivitas-aktivitas sosial di dalamnya. Melalui gambaran umum tentang wilayah Negara Kesatuan Republik Indonesia (NKRI), dikenalkan keberagaman potensi masing-masing daerah. Keberagaman potensi tersebut menciptakan dinamika pasokan-kebutuhan dalam dimensi ruang dan waktu yang memicu tentang pentingnya pembentukan ikatan konektivitas multi dimensi tersebut, sehingga akan menghasilkan kesatuan kokoh dalam keberagaman yang ada (dalam Mushlih, Setiawan, Suciati, dan Dedi, 2014: iii).

Ruang lingkup materi IPS meliputi perilaku sosial, ekonomi dan budaya manusia di masyarakat. Masyarakat merupakan sumber utama IPS. Aspek kehidupan sosial terkait dengan ruang tempat tinggalnya apapun yang dipelajari, apakah itu hubungan sosial, 
ekonomi, budaya, kejiwaan, sejarah, geografis ataukah politik, sumbernya adalah masyarakat. Sebagaimana dijelaskan oleh Winataputra (2007) bahwa visi pendidikan IPS sebagai program pendidikan yang menitikberatkan pada pengembangan individu peserta didik sebagai "aktor sosial" yang mampu mengambil keputusan yang bernalar dan sebagai "warga negara" yang cerdas, memiliki komitmen, bertanggung jawab dan partisipatif. Melalui pendidikan IPS, peserta didik dibina dan dikembangkan kemampuan mental serta intelektualnya menjadi warga Negara yang memiliki keterampilan dan kepedulian sosial serta bertanggung jawab terhadap pembangunan nasional dengan memanfaatkan potensi sumber daya yang ada secara optimal dan lestari (dalam Mukminan, dkk. 9: 2014).

Ruang lingkup materi IPS meliputi perilaku sosial, ekonomi dan budaya manusia di masyarakat. Masyarakat merupakan sumber utama IPS. Aspek kehidupan sosial terkait dengan ruang tempat tinggalnya apapun yang dipelajari, apakah itu hubungan sosial, ekonomi, budaya, kejiwaan, sejarah, geografis ataukah politik, sumbernya adalah masyarakat. Sebagaimana dijelaskan oleh Winataputra (2007, dalam Mukminan, dkk. 9 : 2014) bahwa visi pendidikan IPS sebagai program pendidikan yang menitikberatkan pada pengembangan individu peserta didik sebagai "aktor sosial" yang mampu mengambil keputusan yang bernalar dan sebagai "warga negara" yang cerdas, memiliki komitmen, bertanggung jawab dan partisipatif. Melalui pendidikan IPS, peserta didik dibina dan dikembangkan kemampuan mental serta intelektualnya menjadi warga Negara yang memiliki keterampilan dan kepedulian sosial serta bertanggung jawab terhadap pembangunan nasional dengan memanfaatkan potensi sumber daya yang ada secara optimal dan lestari.

Rendahnya motivasi belajar IPS menyebabkan pembelajaran IPS banyak mengalami kendala untuk memahamkan materi yang disampaikan kepada peserta didik. Kendala pembelajaran antara lain karena kurangnya media dan metode yang merangsang peserta didik untuk lebih aktif didalam proses pembelajaran. Penyampaian materi dengan membaca buku paket dan metode ceramah tidak memberikan ruang gerak peserta didik untuk berkreasi, kurangnya kesempatan siswa untuk tampil, sehingga guru lebih mendominasi daripada siswa.

Kurangnya motivasi belajar peserta didik terhadap IPS juga sangat dirasakan dengan adanya kejenuhan belajar peserta didik ketika proses belajar mengajar sedang berlangsung. Ketidakseriusan ini di lihat dalam belajar IPS peserta didik merasakan bosan dan mengantuk sepanjang proses pembelajaran. Kejenuhan ini juga didapatinya peserta didik bermainmain dengan temannya dengan cara mengganggu antara satu dengan yang lainnya. Kebosanan didalam kelas 
peserta didik mengekspresikan sikap mereka yang tidak proaktif didalam pembelajaran IPS. Indikasi rendahnya motivasi belajar ini berdampak pada rendahnya hasil belajar peserta didik yang terlihat dari observasi guru di kelas VII-5 yang dilaksanakan pada tanggal 5 Februari 2015, yaitu hasil belajar IPS pada peserta didik SMP Negeri 3 Percut Sei Tuan dengan Nilai KKM 70 terdapat ketuntasan belajar 6 peserta didik $(18,75 \%)$, dan yang tidak tuntas sebanyak 32 peserta didik $(84,25 \%)$, dengan nilai rata-rata peserta didik 36,90 dimana nilai tertinggi adalah 86,67 dan nilai terendah 13,33.

Permasalahan rendahnya motivasi belajar siswa ini diakibatkan rendahnya motivasi belajar dan metode pembalajaran IPS yang lebih didominasi pada model ceramah, dan tanpa media sehingga menghilangkan kreatifitas peserta didik untuk lebih tampil dalam berinovasi. Untuk meningkatkan hasil belajar maka diperlukan upaya pembelajaran yang menyenangkan bagi siswa. Peserta didik tidak lagi belajar hanya mendengarkan ceramah guru, duduk diam dan tidak boleh ribut, tetapi peserta didik diupayakan harus lebih aktif dan kreatif dengan metode belajar lebih menarik dan menyenangkan. Untuk itu diperlukan salah satu model pembelajaran kooperatif yang mudah diterapkan dengan melibatkan aktifitas peserta didik tanpa adanya perbedaan status.
Penelitian ini akan difokuskan pada upaya untuk mengatasi lemahnya motivasi belajar siswa dengan meningkatkan inovasi dan kreativitas guru dalam menggunakan pendekatan pembelajaran sehingga kegiatan pembelajaran berlangsung monoton dan membosankan dapat diatasi. Salah satu pendekatan pembelajaran yang diduga mampu mewujudkan situasi pembelajaran yang kondusif, aktif, kreatif, efektif, dan menyenangkan adalah pendekatan dengan model TGT (Team Games Tournament). Menurut Sudjana (1996: 30) yang termasuk dalam komponen pembelajaran adalah "tujuan, bahan, metode dan alat serta penilaian“. Untuk meningkatkan hasil belajar peserta didik perlu dilakukan model pembelajaran kooperatif tipe Team Games Tournament (TGT). Pembelajaran Team Games Tournament adalah salah satu pembelajaran kooperatif yang merangsang aktivitas belajar peserta didik dalam bentuk permainan yang rileks disamping menumbuhkan kerjasama, tanggung jawab dan persaingan belajar untuk berkompetisi untuk mencari yang terbaik.

Penggunaan TGT diharapkan dapat meningkatkan motivasi belajar peserta didik pada materi IPS yang disampaikan oleh guru karena TGT cocok didalam pembelajaran IPS. Pembelajaran ini di dalam Team yaitu peserta didik dibentuk dalam kelompok belajar dan peserta didik harus dapat bekerjasama dengan 
kelompoknya, Tournament menjadikan pembelajaran menjadi menarik karena peserta didik dituntut untuk bersaing didalam belajar secara sehat, ini menumbuhkan tanggungjawab. Permainan atau Games memungkinkan peserta didik yang bermain akan lebih cocok didalam pembelajaran IPS yang berimbas kepada motorik peserta didik dengan lahrinya keterampilan peserta didik.

Berdasarkan permasalah yang dipaparkan di atas, rumusan masalah dalam Penelitian Tindakan Kelas (PTK) ini adalah: Apakah penerapan model Kooperatif Tipe TGT (Team Games Tournament) dapat meningkatkan motivasi belajar siswa pada Mata Pelajaran IPS di kelas VII-5 SMP Negeri 3 Percut Sei Tuan?

Tujuan yang diharapkan setelah penelitian ini adalah meningkatkan motivasi belajar siswa pada Mata Pelajaran IPS setelah penerapan model Kooperatif Tipe TGT (Team Games Tournament).

\section{METODOLOGI PENELITIAN}

Metode penelitian yang digunakan dalam penelitian ini berupa penelitian tindakan kelas (Classroom Action Research), yaitu penelitian yang dilakukan oleh guru kelas atau di sekolah tempat ia mengajar dengan penekanan pada penyempurnaan atau peningkatan proses dan praktis pembelajaran (Arikunto, 2006: 96). Penelitian tindakan kelas ini dilaksanakan di
SMP Negeri 3 Percut Sei Tuan Kabupaten Deli Serdang yang di mulai pada bulan Maret sampai dengan bulan Mei 2015. Penelitian dilaksanakan sebanyak 2 siklus, masing masing siklus 4 kali pertemuan ( $8 \quad \mathrm{x} \quad 40$ menit) yang rencana dilaksanakan pada minggu ke-2 bulan Maret 2015 sampai dengan minggu ke-1 bulan Mei 2015. Selama penelitian untuk mengamati proses pembelajaran dan membantu pengumpulan data peneliti dibantu oleh 1 observer teman guru di SMP Negeri 3 Percut Sei Tuan.

Subjek penelitian adalah seluruh peserta didik kelas VII-5 SMP Negeri 1 kecamatan Percut Sei Tuan tahun ajaran 2014-2015 yang berjumlah 36 peserta didik yang terdiri dari laki-lak 17 peserta didik dan perempuan 19 peserta didik dengan kemampuan peserta didik yang berbeda.

Defenisi operasional yang menjadi indikator motivasi belajar siswa adalah dorongan dan kebutuhan dalam belajar, yang memiliki ciri; tekun mengerjakan tugas, tahan menghadapi kesulitan, senang belajar mandiri, percaya pada kemampuan, senang mencari dan memecahkan soal-soal, sehingga belajar menjadi hal yang menarik dan terjadi perlombaan di lingkungan belajar, untuk mencapai keberhasilan siswa dalam pembelajaran IPS di kelas VII.

Penelitian direncanakan akan berlangsung selama dua siklus, yang masing-masing terdiri dari: perencanaan (plan), pelaksanaan 
(act), pengamatan (observe), dan refleksi (reflect). Tiap siklus minimal akan terdiri dari 3 sampai dengan 4 pertemuan tatap muka sehingga keseluruhan penelitian akan terdiri dari sekitar dua belas pertemuan tatap muka. Siklus "plan - act observe - reflect" akan berlangsung terus sampai kriteria keberhasilan mencapai minimal $60 \%$ dari indikator motivasi belajar yang terdapat pada $75 \%$ siswa.

Instrumen penelitian yang digunakan untuk pengumpulan data dalam penelitian tindakan kelas ini berupa instrumen nontes (berupa lembar observasi dan catatan harian), dan instrument tes. Tes instrumen pengumpulan data untuk mengukur kemampuan peserta didik dalam aspek kognitif, atau tingkat penguasaan materi pelajaran. Bentuk instrumen yang digunakan berupa tes Unjuk Kerja secara individual.

Data hasil belajar siswa akan dianalisis dengan statistik deskriptif, seperti rata-rata dan persentase. Peningkatan motivasi belajar akan dilihat dari kecenderungan kenaikan motivasi yang diperoleh dari format observasi dan catatan lapangan (field notes). Data dari lembar observasi dan pedoman wawancara akan dianalisis secara kualitatif, kemudian dilihat juga kecenderungannya dari siklus ke siklus.

Kolaborator penelitian adalah teman sejawat yang masuk pada kelas yang sama meski mengampu mata pelajaran yang berbeda. Pada saat-saat tertentu, kolaborator ikut masuk kelas untuk membantu melakukan observasi dan membantu mengamati pelaksanaan pembelajaran dengan model pembelajaran model TGT (Team Games Tournament). Kolaborasi juga dilakukan untuk menerima saran tentang perencanakan tindakan untuk minggu berikutnya.

\section{HASIL PENELITIAN DAN PEMBAHASAN}

Perencanaan siklus didasarkan pada temuan observasi awal yang disimpulkan, peserta didik yang mengikuti Evaluasi KD 4.1 ternyata hanya $16.67 \%$ yang tuntas belajar, $83.33 \%$ tidak tuntas, nilai tertinggi 80 , nilai terendah 28 , dan nilai ratarata hasil belajar 51.66 dengan nilai KKM (Kriteria Ketuntasan Minimal) adalah 70, jumlah peserta didik yang hadir 36 orang (100\%). Sedangkan berdasarkan pengujian motivasi belajar hanya $4.65 \%$ yang memiliki Motivasi Baik Sekali, $9.30 \%$ memiliki Motivasi Baik, 23.26\% memiliki Motivasi Sedang, dan 46.51\% memiliki Motivasi belajar Kurang, dengan rerata capaian $43.99 \%$ dari indikator motivasi belajar siswa.

\section{Siklus I}

\section{Perencanaan}

Penelitian pada siklus I ini dilakukan sebanyak 4 pertemuan (8 x 40 menit). Perencanaan yang dilakukan pada siklus I adalah:

a. Membuat Rencana Pelaksanaan Pembelajaran (RPP) yang akan dilaksanakan dengan 
menggunakan model TGT (Team Games Tournament).

b. Membuat format evaluasi (penilaian) belajar untuk mengetahui sejauhmana capaian keberhasilan pemahaman materi pelajaran setelah dilaksanakan TGT (Team Games

Tournament).

c. Mempersiapkan soal dan lembar hasil belajar peserta didik saat evaluasi hasil belajar peserta didik.

d. Menyusun format format penilaian (unjuk kerja) dan observasi.

e. Mempersiapkan format observasi motivasi belajar peserta didik dan catatan lapangan (field note) yang akan diamati oleh peneliti dan/atau observer.

\section{Pelaksanaan Tindakan Siklus I}

Awal pembelajaran pertemuan dilakukan pretest, dilanjutkan pada tahap pembangkitan minat atau engagement. Pada tahap game dan turnamen guru membagi kelompok untuk turnamen dan setiap meja turnamen terdiri dari 6 peserta. Guru meminta siswa untuk mengambil kartu yang berisikan nomor dan siswa yang mendapatkan nomor tertinggi menjadi pembaca yang pertama. Guru meminta pembaca pertama mengocok kartu dan mengambil kartu teratas. Setelah itu membacakan dan menjawab soal sesuai nomor yang ada pada kartu kemudian guru bertanya apakah penantang pertama mempunyai opsi jawaban yang berbeda atau ingin melewatinya dan jika penantang kedua ingin menantang dengan opsi yang berbeda dengan dua peserta pertama, maka penantang kedua boleh menantang selanjutnya guru meminta penantang kedua untuk membacakan jawaban yang benar. Pemain yang memberikan jawaban yang benar akan menyimpan kartunya dan jika jawaban kedua penantang salah, maka mereka harus mengembalikan kartu yang telah dimenangkan, guru meminta siswa bergeser satu posisi ke kiri, dan melanjutkan permainan sampai pertanyaan yang disediakan habis.

Tahap menghitung skor perkembangan individu tidak dilakukan karena keterbatasan pada jumlah observer, selain memakan waktu yang lama. Rekognisi tim, tahap ini guru mengumumkan kelompok terbaik sementara, selanjutnya meminta perwakilan kelompok untuk maju ke depan dan memberikan penghargaan kepada perwakilan kelompok yang memiliki nilai tertinggi. Tahap akhir yaitu penutup, guru membimbing siswa untuk membuat kesimpulan dari materi yang telah dipelajari dan menginformasikan pertemuan selanjutnya.

\section{Pengamatan}

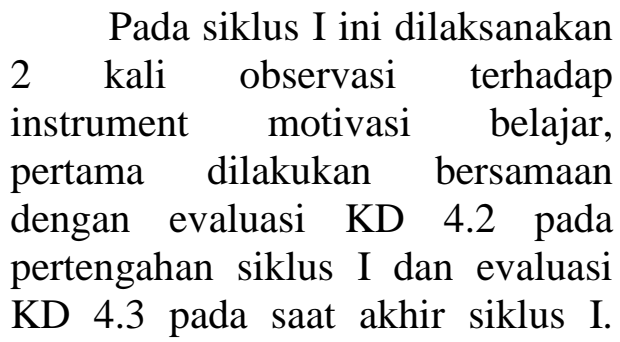


Data yang diperoleh dari kedua evaluasi ini menunjukkan telah terjadi peningkatan ketuntasan belajar siswa dari sebelum menggunakan model TGT (Team
Games Tournament). Peningkatan hasil belajar dan motivasi ditunjukkan dalam tabel 4.5 dan tabel 4.8 berikut:

Tabel 4.5.

Perbandingan Hasil Evaluasi Belajar Sebelum dan Setelah Menggunakan model TGT (Team Games Tournament) Pada Siklus I

\begin{tabular}{|c|c|c|c|c|c|c|}
\hline \multirow{2}{*}{$\begin{array}{c}\text { Perbandingan Hasil } \\
\text { Belajar }\end{array}$} & \multicolumn{2}{|c|}{ Observasi Awal } & \multicolumn{4}{|c|}{ Observasi Pada Siklus I } \\
\cline { 4 - 7 } & & \multicolumn{2}{|c|}{ Observasi I } & \multicolumn{2}{c|}{ Observasi II } \\
\hline Nilai Tertinggi & 80 & & 100 & & 100 & \\
\hline Nilai Terendah & 28 & & 37.5 & & 50 & \\
\hline Rata-Rata Nilai & 51.33 & & 66.49 & & 70.14 & \\
\hline Ketuntasan & 6 & $16.67 \%$ & 12 & $33.33 \%$ & 23 & $63.89 \%$ \\
\hline Tidak Tuntas & 30 & $83.33 \%$ & 24 & $66.67 \%$ & 13 & $36.11 \%$ \\
\hline KEHADIRAN & & & & & & \\
\hline Hadir & 36 & $100 \%$ & 36 & $100 \%$ & 36 & $100 \%$ \\
\hline Tidak Hadir & 0 & $0 \%$ & 0 & $0 \%$ & 0 & $0 \%$ \\
\hline Jumlah Keseluruhan & 36 & $100 \%$ & 36 & $100 \%$ & 36 & $100 \%$ \\
\hline
\end{tabular}

Tabel 4.8.

Perbandingan Kualitas Motivasi Belajar Sebelum dan Sesudah Menggunakan model TGT (Team Games Tournament) Pada Siklus I

\begin{tabular}{|c|c|c|c|c|c|c|c|c|c|}
\hline \multirow{3}{*}{$\begin{array}{c}\text { Perbandingan } \\
\text { Kualitas Motivasi } \\
\text { Belajar }\end{array}$} & \multirow{2}{*}{\multicolumn{3}{|c|}{ Observasi Awal }} & \multicolumn{6}{|c|}{ Observasi Pada Siklus I } \\
\hline & & & & \multicolumn{3}{|c|}{ Observasi I } & \multicolumn{3}{|c|}{ Observasi II } \\
\hline & $\mathrm{Jlh}$ & $\%$ & & $\mathrm{Jlh}$ & $\%$ & & $\mathrm{Jlh}$ & $\%$ & \\
\hline Baik Sekali & 2 & $5.56 \%$ & \multirow{2}{*}{$16.67 \%$} & 4 & $11.11 \%$ & \multirow{2}{*}{$33.33 \%$} & 8 & $22.22 \%$ & \multirow{2}{*}{$61.11 \%$} \\
\hline Baik & 4 & $11.11 \%$ & & 8 & $22.22 \%$ & & 14 & $38.89 \%$ & \\
\hline Sedang & 10 & $27.78 \%$ & \multirow{2}{*}{$83.33 \%$} & 11 & $30.56 \%$ & \multirow{2}{*}{$66.67 \%$} & 7 & $19.44 \%$ & \multirow{2}{*}{$38.89 \%$} \\
\hline Kurang & 27 & $55.56 \%$ & & 13 & $36.11 \%$ & & 7 & $19.44 \%$ & \\
\hline Jumlah & 36 & $100.00 \%$ & $100.00 \%$ & 36 & $100.00 \%$ & $100.00 \%$ & 36 & $100.00 \%$ & $100.00 \%$ \\
\hline Rerata Capaian & 15.84 & $43.99 \%$ & & 20.42 & $46.40 \%$ & & 22.28 & $69.62 \%$ & \\
\hline
\end{tabular}

\section{Refleksi}

Berdasarkan dari temuan, maka telah terjadi peningkatan motivasi belajar siswa kearah yang makin baik setelah dilakukan perubahan metode belajar model TGT (Team Games Tournament).
Pada observasi awal ditemukan siswa yang bermotivasi tinggi (Baik dan Baik Sekali) hanya sebanyak $16.67 \%$, dengan rerata capaian $43.99 \%$ dari indikator motivasi belajar siswa pada awal observasi, selanjutnya mengalami kenaikan 
menjadi $33.33 \%$ dengan rerata capaian $46.40 \%$ dari indikator motivasi belajar siswa pada pertengahan siklus I dan menjadi $61.11 \%$ dengan rerata capaian $69.62 \%$ dari indikator motivasi belajar siswa pada akhir siklus I.

Peningkatan ketuntasan

belajar juga mengalami kenaikan antara sebelum dan sesudah menggunakan model TGT (Team Games Tournament). Pada observasi awal ketuntasan belajar hanya pada 6 orang siswa (16.67\%), setelah menggunakan model TGT (Team Games Tournament) mengalami kenaikan pada pertengahan siklus I yaitu menjadi 12 orang siswa $(33.33 \%)$ dan menjadi 23 orang siswa (63.89\%) pada akhir siklus I.

Berdasarkan data dan uraian diatas maka disimpulkan masih diperlukan usaha perencanaan dan pengembangan yang lebih matang dalam pelaksanaan model TGT (Team Games Tournament) yang paling ideal dalam meningkatkan motivasi belajar siswa. Untuk itulah penggunaan model TGT (Team Games Tournament) ini akan dilanjutkan pada siklus II, agar kriteria keberhasilan mencapai minimal $60 \%$ dari indikator motivasi belajar yang terdapat pada $75 \%$ siswa.

\section{Data Siklus II}

\section{Perencanaan}

Pelaksanaannya penelitian dalam siklus II ini peneliti dibantu seorang observer yang merupakan rekan kerja sesama guru untuk membantu proses observasi dan memberikan catatan lapangan selain yang dilakukan oleh peneliti. Penelitian dalam siklus II ini dilakukan sebanyak 4 kali pertemuan (8 x 40 menit).

Bentuk perencanaan pada siklus II ini meliputi :

a. Menyiapkan Rencana Pelaksanaan Pembelajaran yang sesuai dengan Standar Kompetensi dan Kompetensi dasar untuk mata pelajaran IPS Kelas VII, dan mengembangkan skenario pembelajaran.

b. Membuat Rencana Pelaksanaan Pembelajaran (RPP) yang akan dilaksanakan pada siklus II ini dengan menggunakan model TGT (Team Games Tournament).

c. Melanjutkan kelompok yang telah ada sebelumnya untuk melaksanakan rencana pembelajaran.

d. Mempersiapkan format observasi motivasi belajar peserta didik dan catatan lapangan (field note) yang akan diamati oleh peneliti dan/atau observer.

\section{Pelaksanaan tindakan siklus II}

Guru membagi kelompok untuk turnamen dan setiap meja turnamen terdiri dari 6 peserta. Guru membimbing siswa untuk melaksanakan game seperti sebelumnya dan mengamati perkembangan motivasi siswa dibantu oleh guru observer 
pembantu. Penghitungan skor perkembangan individu tidak dilakukan karena keterbatasan pada jumlah observer, dan memakan waktu yang lama. Rekognisi tim, pada tahap ini guru mengumumkan kelompok terbaik sementara, selanjutnya guru meminta perwakilan kelompok untuk maju ke depan dan memberikan penghargaan dan hadiah (makanan ringan) kepada kelompok yang memiliki nilai tertinggi. Tahap akhir yaitu penutup, guru membimbing siswa untuk membuat kesimpulan dari materi yang telah dipelajari dan menginformasikan pertemuan selanjutnya.

\section{Pengamatan}

Pada siklus II ini dilaksanakan 2 kali observasi terhadap instrument motivasi belajar, yaitu pada pertengahan siklus dan pada akhir siklus bersamaan dengan evaluasi KD 4.4. Kedua evaluasi ini menunjukkan bahwa diperoleh data peningkatan motivasi belajar yang ternyata diiringi dengan peningkatan ketuntasan belajar siswa.

Hasil pengamatan terhadap instrument motivasi dan hasil evaluasi belajar siswa pada siklus II serta perbandingan dengan siklus I dan observasi awal ditunjukkan pada tabel-tabel berikut:

Tabel 4.12.

Perbandingan Kualitas Motivasi Belajar Sebelum Dan Sesudah Menggunakan model TGT (Team Games Tournament)

\begin{tabular}{|c|c|c|c|c|c|c|c|c|c|c|c|c|c|c|c|}
\hline \multirow{3}{*}{$\begin{array}{c}\text { Perbandingan } \\
\text { Kualitas } \\
\text { Motivasi } \\
\text { Belajar }\end{array}$} & \multirow{2}{*}{\multicolumn{3}{|c|}{ Observasi Awal }} & \multicolumn{6}{|c|}{ Observasi Pada Siklus I } & \multicolumn{6}{|c|}{ Observasi Pada Siklus II } \\
\hline & & & & \multicolumn{3}{|c|}{ Observasi I } & \multicolumn{3}{|c|}{ Observasi II } & \multicolumn{3}{|c|}{ Observasi I } & \multicolumn{3}{|c|}{ Observasi II } \\
\hline & $\mathrm{Jlh}$ & $\%$ & & Jlh & $\%$ & & $\mathrm{Jlh}$ & $\%$ & & $\mathrm{Jlh}$ & $\%$ & & $\mathrm{Jlh}$ & $\%$ & \\
\hline Baik Sekali & 2 & $5.56 \%$ & \multirow{2}{*}{$\begin{array}{c}16.67 \\
\%\end{array}$} & 4 & $\begin{array}{c}11.11 \\
\%\end{array}$ & \multirow{2}{*}{$33.33 \%$} & 8 & $22.22 \%$ & \multirow{2}{*}{$\begin{array}{c}61.11 \\
\%\end{array}$} & 11 & $30.56 \%$ & \multirow{2}{*}{$\begin{array}{c}80.56 \\
\%\end{array}$} & 17 & $\begin{array}{c}47.22 \\
\%\end{array}$ & \multirow{2}{*}{$91,67 \%$} \\
\hline Baik & 4 & $11.11 \%$ & & 8 & $\begin{array}{c}22.22 \\
\%\end{array}$ & & 14 & $38.89 \%$ & & 18 & $50.00 \%$ & & 16 & $\begin{array}{c}44.44 \\
\%\end{array}$ & \\
\hline Sedang & 10 & $27.78 \%$ & \multirow{2}{*}{$\begin{array}{c}83.33 \\
\%\end{array}$} & 11 & $\begin{array}{c}30.56 \\
\%\end{array}$ & \multirow{2}{*}{$66.67 \%$} & 7 & $19.44 \%$ & \multirow{2}{*}{$\begin{array}{c}38.89 \\
\%\end{array}$} & 5 & $13.89 \%$ & \multirow{2}{*}{$\begin{array}{c}22.73 \\
\%\end{array}$} & 2 & $5.56 \%$ & \multirow{2}{*}{$8,33 \%$} \\
\hline Kurang & 27 & $55.56 \%$ & & 13 & $\begin{array}{c}36.11 \\
\%\end{array}$ & & 7 & $19.44 \%$ & & 2 & $5.56 \%$ & & 1 & $2.78 \%$ & \\
\hline Jumlah & 36 & $100.00 \%$ & $\begin{array}{c}100.00 \\
\%\end{array}$ & 36 & $\begin{array}{c}100.00 \\
\%\end{array}$ & $\begin{array}{c}100.00 \\
\%\end{array}$ & 36 & $100.00 \%$ & $\begin{array}{c}100.00 \\
\%\end{array}$ & 36 & $100.00 \%$ & $\begin{array}{c}100.00 \\
\%\end{array}$ & 36 & $\begin{array}{c}100.0 \\
0 \%\end{array}$ & $100.00 \%$ \\
\hline $\begin{array}{c}\text { Rerata } \\
\text { Capaian }\end{array}$ & & $43.99 \%$ & & & \begin{tabular}{|c|}
46.40 \\
$\%$
\end{tabular} & & & $69.62 \%$ & & & $\mathbf{7 5 . 0 9 \%}$ & & & \begin{tabular}{|c|}
80.99 \\
$\%$
\end{tabular} & \\
\hline
\end{tabular}


Tabel 4.13.

Perbandingan Hasil Evaluasi Belajar Sebelum dan Setelah Menggunakan model TGT (Team Games Tournament)

\begin{tabular}{|c|c|c|c|c|c|c|c|c|}
\hline \multirow{3}{*}{$\begin{array}{c}\text { Perbandingan Hasil } \\
\text { Belajar }\end{array}$} & \multirow{2}{*}{\multicolumn{2}{|c|}{ Observasi Awal }} & \multicolumn{4}{|c|}{ Observasi Pada Siklus 1} & \multirow{2}{*}{\multicolumn{2}{|c|}{$\begin{array}{l}\text { Observasi Pada } \\
\text { Siklus } 2\end{array}$}} \\
\hline & & & \multicolumn{2}{|c|}{ Observasi 1} & \multicolumn{2}{|c|}{ Observasi 2} & & \\
\hline & 80 & & 100 & & 100 & & 100 & \\
\hline Nilai Terendah & 28 & & 37.5 & & 50 & & 65 & \\
\hline Rata-Rata Nilai & 51.33 & & 66.49 & & 70.14 & & 80.28 & \\
\hline Ketuntasan & 6 & $16.67 \%$ & 12 & $33.33 \%$ & 23 & $63.89 \%$ & 31 & $86.11 \%$ \\
\hline Tidak Tuntas & 30 & $83.33 \%$ & 24 & $66.67 \%$ & 13 & $36.11 \%$ & 5 & $13.89 \%$ \\
\hline \multicolumn{9}{|l|}{ KEHADIRAN } \\
\hline Hadir & 36 & $100 \%$ & 36 & $100 \%$ & 36 & $100 \%$ & 36 & $100 \%$ \\
\hline Tidak Hadir & 0 & $0 \%$ & 0 & $0 \%$ & 0 & $0 \%$ & 0 & $0 \%$ \\
\hline $\begin{array}{l}\text { Jumlah } \\
\text { Keseluruhan }\end{array}$ & 36 & $100 \%$ & 36 & $100 \%$ & 36 & $100 \%$ & 36 & $100 \%$ \\
\hline
\end{tabular}

\section{Refleksi}

Berdasarkan dari temuan diatas maka dapat dikatakan bahwa telah terjadi peningkatan motivasi belajar siswa kearah yang makin baik, hal ini terlihat dari terus berkurangnya siswa yang memiliki motivasi belajar rendah (Sedang dan Kurang) antara sebelum dan sesudah menggunakan metode model TGT (Team Games Tournament). Peningkatan terus terjadi ketika dilaksanakan siklus 2, dimana pada pertengahan siklus 2 siswa yang bermotivasi tinggi (Baik dan Baik Sekali) sudah mencapai $80.56 \%$, dengan rerata capaian $75.09 \%$ dari indikator motivasi belajar siswa, dan pada akhir siklus 2 peningkatan ketuntasan belajar mencapai $91,67 \%$ dengan rerata capaian $80.99 \%$ dari indikator motivasi belajar siswa dengan kehadiran siswa $100 \%$.

\section{Pembahasan}

Berdasarkan temuan-temuan diatas maka disimpulkan telah terjadi peningkatan motivasi belajar siswa yang makin baik setelah dilakukan perubahan metode belajar menggunakan model TGT (Team Games Tournament). Hal ini ditunjukkan dengan berkurangnya siswa yang bermotivasi belajar rendah (Sedang dan Kurang) antara sebelum dan sesudah menggunakan model TGT (Team Games Tournament).

Pada observasi awal ditemukan siswa yang bermotivasi tinggi (Baik dan Baik Sekali) hanya sebanyak $16.67 \%$ pada awal observasi, selanjutnya mengalami kenaikan menjadi $33.33 \%$ pada pertengahan siklus 1 dan menjadi $61.11 \%$ pada akhir siklus 1 . Peningkatan terus terjadi ketika dilaksanakan siklus 2, dimana pada pertengahan siklus 2 siswa yang bermotivasi tinggi (Baik dan Baik 
Sekali) sudah mencapai $80.56 \%$ dengan rerata capaian $75.09 \%$ dari indikator motivasi belajar siswa. Pada akhir siklus 2 peningkatan motivasi mencapai $91,67 \%$ dengan rerata capaian $80.99 \%$ dari indikator motivasi belajar siswa.

Peningkatan ketuntasan

belajar juga mengalami kenaikan antara sebelum dan sesudah menggunakan model TGT (Team Games Tournament). Pada observasi awal ketuntasan belajar hanya pada 6 orang siswa (16.67\%), setelah menggunakan model TGT (Team Games Tournament) mengalami kenaikan pada pertengahan siklus 1 yaitu menjadi 12 orang siswa (33.33\%), dan menjadi 23 orang siswa (63.89\%) pada akhir siklus 1 . Peningkatan terus terjadi ketika dilaksanakan siklus 2, dimana pada akhir siklus 2 ketuntasan belajar siswa bahkan mencapai $86.11 \%$ dengan kehadiran siswa $100 \%$.

Hasil penelitian ini juga menguatkan penelitian sebelumnya oleh Raodatul Jannah "Penerapan Model Pembelajaran Kooperatif Tipe TGT (Team Games Tournament) Untuk Meningkatkan Hasil Belajar Biologi (Penelitian Tindakan Kelas di Kelas VIII Satu Atap Karangkobong)" Program Studi Pendidikan Biologi Fakultas Ilmu Tarbiyah dan Keguruan Universitas Islam Negeri Syarif Hidayatullah Jakarta 2014. Penelitian Fitrianto di Kabupaten Deli Serdang yang berjudul "Peningkatan Hasil Belajar Perserta
Didik Pada Mata Pelajaran IPS Melalui Penerapan model Pembelajaran Kooperatif Tipe TGT (Team Games Turnament) di kelas IX-1 SMP Negeri 1 Batang Kuis Tahun Ajaran 2014/2015 (Penelitian Tindakan Kelas)". Penelitian-penelitian ini menyimpulkan bahwa model pembelajaran kooperatif tipe TGT (Team Games Turnament) dapat meningkatkan hasil belajar siswa.

\section{SIMPULAN DAN SARAN}

Penggunaan model pembelajaran kooperatif tipe TGT (Team Games Turnament) terbukti mampu menghilangkan kejenuhan siswa dan meningkatkan motivasi belajar siswa dibandingkan menggunakan metode konvensional.

Penggunaan model pembelajaran kooperatif tipe TGT (Team Games Turnament) telah mengurangi siswa yang memiliki motivasi belajar rendah (Sedang dan Kurang). Pada observasi awal ditemukan siswa yang bermotivasi tinggi (Baik dan Baik Sekali) hanya sebanyak $16.67 \%$ dengan rerata capaian $43.99 \%$ dari indikator motivasi belajar siswa pada awal observasi. Kenaikan motivasi belajar siswa terus terjadi menjadi $33.33 \%$ pada pertengahan siklus 1 dengan rerata capaian $46.40 \%$ dari indikator motivasi belajar siswa pada pertengahan siklus 1 dan menjadi $61.11 \%$ dengan rerata capaian $69.62 \%$ dari indikator motivasi belajar siswa pada akhir siklus 1 . 
Peningkatan terus terjadi ketika dilaksanakan siklus 2, dimana pada pertengahan siklus 2 siswa yang bermotivasi tinggi (Baik dan Baik Sekali) sudah mencapai $80.56 \%$ dengan rerata capaian $75.09 \%$ dari indikator motivasi belajar siswa. Pada akhir siklus 2 peningkatan motivasi mencapai $91,67 \%$ dengan rerata capaian $80.99 \%$ dari indikator motivasi belajar siswa.

Keberhasilan penggunaan model pembelajaran kooperatif tipe TGT (Team Games Turnament) ini tidak terlepas dari perubahan tindakan yang dilakukan guru terhadap siswa. Pemberian reward berupa pujian dan hadiah terhadap kelompok yang menang membuat siswa makin semangat. Pada akhirnya meningkatkan setiap hasil yang hendak dicapai, baik motivasi maupun hasil evaluasi belajar siswa secara keseluruhan.

\section{DAFTAR RUJUKAN}

Anni, Chatarina Tri. 2007. Psikologi Belajar. Semarang: UPT MKK UNNES.

Arikunto, Suharsimi. 2006. Prosedur Penelitian Suatu Pendekatan Praktik. Jakarta: Rineka Cipta.

Dimyati, Mudjiono. 2002. Belajar dan Pembelajaran, Studi dan Pengajaran. Rineka Cipta: Jakarta.

Djamarah, Syaiful Bahri. 2002. Psikologi Belajar. Jakarta: PT Asdi Mahasatya.

Ibrahim, Muslimin. dkk. 2000. Pembelajaran Kooperatif. Surabaya: UNESA Press.

Jannah, Raodatul. 2014. Penerapan Model

Pembelajaran
Kooperatif Tipe TGT (Team Games Tournament) Untuk Meningkatkan Hasil Belajar Biologi (Penelitian Tindakan Kelas di Kelas VIII Satu Atap Karangkobong).

(Online),http://repository.uinjkt .ac.id/dspace/bitstream/123456 789/25292/1/RAODATUL\%20 JANNAH-FITK.pdf (diunduh pada 9 Maret 2015).

Makmun, Abin Syamsudin. 2007. Psikologi Kependidikan; Perangkat Sistem Pengajaran Modul. Cetakan ke 10. Bandung: PT Remaja Rosdakarya.

Mohamad Surya. 2004. Psikologi Pembelajaran dan Pengajaran. Bandung: Pustaka Bani Quraisy.

Mukminan, Mulyani, E., Nursa'ban, M., dan Supardi. 2014. Buku Guru Ilmu Pengetahuan Sosial. Jakarta: Pusat Kurikulum dan Perbukuan, Balitbang, Kemdikbud.

Mulyasa, Eco. 2003. Kurikulum Berbasis Kompetensi Konsep, Karakteristik dan Implementasi.

Mushlih, A., Setiawan, I., Suciati, dan Dedi. 2014. Ilmu Pengetahuan Sosial Edisi Revisi. Jakarta: Pusat Kurikulum dan Perbukuan, Balitbang, Kemdikbud.

Nur, Mohammad. 2005. Pembelajaran Kooperatif. UNESA Press: Surabaya.

Nur, M. dan Wikandari, P. R. 2000. Pengajaran Berpusat kepada Peserta didik dan Pendekatan Kontruktivs dalam Pengajaran. Surabaya: PSMS Program Pasca Sarjana IKIP Surabaya. 
Purwoto. 2000. Strategi Belajar Mengajar Matematika. Surakarta: UNS Press.

Sardiman, AM. 2011. Interaksi dan Motivasi Belajar Mengajar. Jakarta: PT Raja Grafindo Persada.

Siberman, Melvin L. 2004. Active Learning. (Raisul Mutaqqin, Terjemahan). Bandung: Penerbit Nusa Indah Media dan Penerbit Nuansa.

Slameto. 2003. Belajar dan faktorfaktor yang mempengaruhinya. Jakarta: Rineka Cipta.

Slavin, Robert E. 2008. Cooperative Learning Teori, Riset, dan Praktik. Bandung: Nusa Media. Sudjana, Nana. 1996. Cara Belajar Peserta didik Aktif Dalam Proses Belajar Mengajar. Bandung: Sinar Baru Algensindo.

Sanjaya, W. 2009. Strategi Pembelajaran. Jakarta: Kencana Prenada Media
Group.

Sobour, Alex. 2003. Psikologi Umum dalam Lintasan Sejarah. Bandung: CV Pustaka Setia.

Sunarto. 2012. Pengertian Prestasi Belajar.

(Online), http://sunartombs.wordpress.co $\mathrm{m} / 2009 / 01 / 05 /$ pengertianprestasi-belajar/. (diunduh pada 9 Maret 2015).

Suryabrata, Sumadi. 2011. Psikologi Pendidikan. Jakarta: PT Raja Grafindo Persada.

Trianto. 2009. Mendesain Model Pembelajaran InovatifProgresif. Jakarta: Penerbit Kencana Prenada Media Group.

Undang-Undang Republik Indonesia Nomor 20 Tahun 2003. Sistem Pendidikan Nasional. Jakarta: Kementerian Pendidikan Nasional.

Uno, Hamzah. 2009. Teori Motivasi dan Pengukurannya. Jakarta: Bumi Aksara. 